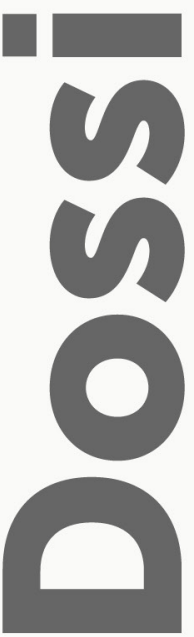

\title{
Imágenes para el duelo: Etnografía sobre el cuidado y las representaciones de la muerte en torno a los desaparecidos en Argentina
}

\author{
Images for mourning: Ethnography on care and representa- \\ tions of death regarding victims of enforced disappearance in \\ Argentina

\section{RESUMEN}

Este texto analiza las prácticas de duelo frente a la desaparición de personas por razones políticas en Argentina. Utilizo las herramientas de la antropología para observar etnográficamente las maneras y modos con los cuales los familiares de desaparecidos construyen la relación con sus muertos ¿Cómo se transita el duelo cuando no hay cuerpo, ni tumba? ¿Qué elementos se pueden distinguir en los procesos donde la muerte debe ser imaginada? ¿Qué rituales y acciones se ponen en juego para el cuidado de esos muertos? En la primera parte se trazan los elementos centrales para comprender la desaparición dentro de la noción de muerte. A continuación se establecen los nexos entre imagen, duelo y desaparición. Finalmente se centra en las acciones, rituales y prácticas en torno al cuidado de los muertos frente a la falta del cuerpo, específicamente observado a partir de cuatro historias de hijos de desaparecidos y la relación que establecen con la fotografía policial de sus padres del "Registro de Extremistas".

Palabras Clave: Duelo - Desaparición - Muerte - Fotografía - Etnografía

\begin{abstract}
In this study, I am interested in analyzing practices of mourning regarding politically-related disappearances in Argentina. Here I use anthropological tools to ethnographically observe the ways in which the relatives of enforced disappearance victims build their relationship with the dead. How is grief experienced when there is no body and no grave? What elements can be distinguished in processes where death has to be imagined? What rituals and actions are put into play to care for the dead? In the first part, central elements are outlined so as to understand disappearance within the notion of death. Afterwards, links between image, mourning and disappearance are established. Accordingly, we observe the space that photography occupies in the face of disappearances, inhabiting the imprint of that absence and a place of singular memory for the mourning. Finally, ethnography focuses on the actions, rituals and practices around the care of the dead in connection with the absence of a body, specifically seen in four accounts given by the children of missing persons and the relationship they establish with police photographs of their parents, taken for the "Register of Extremists".
\end{abstract}

Keywords: Mourning - Enforced Disappearance - Death - Photography - Ethnography

* Doctora en Ciencias Humanas, orientación Antropología Cultural por la Universidade Federal do Río de Janeiro (UFRJ). Investigadora del Instituto de Antropología Córdoba (IDACOR). Directora del Museo de Antropología de la Universidad Nacional de Córdoba (UNC). Investigadora del Consejo Nacional de Investigaciones Científicas y Técnicas (CONICET). CV: http://flacso.org.ar/ / da-silva-catela-ludmila-gilda-veronica/ 
¿Qué es la muerte para usted?

Depende de la hora del día. A veces me angustia. A veces le tengo miedo. A veces me resulta indiferente, y otras veces, las más frecuentes, creo que la muerte y el nacimiento son hermanos. Que la muerte ocurre para que el nacimiento sea posible. Y que hay nacimientos para confirmar que la muerte nunca mata del todo. (Galeano, 2008, p. 2)

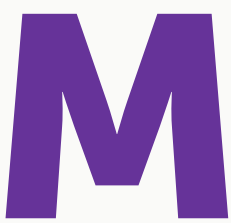

i abuela Amanda me llevaba una vez al mes al cementerio a ver a sus muertos. Nos subíamos al auto de mi abuelo, un Chevy verde enorme, junto con los baldes, las flores, el agua y alguna franela. Transitábamos en silencio los 5 kilómetros que separaban el pueblo del cementerio. Mi abuelo siempre renegaba de esta actividad. Allí en ese cementerio no estaban sus muertos. Ir, era un programa de mi abuela, como muchas de las cosas que sucedían en esa casa. Estacionaba el auto afuera y caminábamos hasta el panteón, al que yo llamaba "la casita". El ritual era siempre el mismo, primero abríamos las puertas, luego mi abuela barría y limpiaba el piso. Mi abuelo se iba a caminar por los pasillos del cementerio con sus manos hacia atrás, como quien recorre un barrio. Yo a veces me escapaba de la mirada de los adultos y corría hasta el gran paredón lleno de nichos, que cada tanto, tenía la foto de un niño o de alguna persona conocida de mi pueblo. Era extraño. Sentía miedo y curiosidad a la vez.

Mi abuela terminaba con la limpieza, sacaba las flores podridas o secas y me mandaba a buscar agua para los floreros. Recuerdo el olor nauseabundo de las flores, "olor a cementerio". Cuando yo llegaba con el agua en los floreros, ella ordenaba pacientemente las flores nuevas y después en un ritual que se repetía, tocaba cada una de las fotos en silencio. Se acercaba lentamente y las besaba. Mientras pasaba la franela sobre la imagen de sus tíos, abuelos, madre y padre me decía: "Ludmila estos son tus antepasados, hay que visitarlos, cuidarlos y recordarlos".

Cuando mi abuela murió yo estaba en Buenos Aires. Me llamaron para decirme que no podrían esperar a que llegue para enterrarla. Quise saber si había sufrido al morir. Sólo se durmió, me respondieron. Pensé mucho en el lugar que su cuerpo ocuparía en "la casita". Me pregunté, ¿quién la cuidaría?, ¿quién visitaría a sus muertos ahora que ella ya no estaba? Volví una sola vez al cementerio, a llevarle flores a mi abuela. Nadie de la familia recogió la tarea del cuidado de nuestros muertos. Yo reemplacé la visita, por las fotos de mis antepasados en mi casa, con flores o una vela en su fecha de cumpleaños y en la transmisión a mis hijos de sus historias.

Esta experiencia de niña, el cuidado que mi abuela me transmitió, forman parte de un mundo de afectos muy personales, pero también de una forma de entender la muerte, sus rituales y las maneras con la que lidiamos con ella. Pensar los afectos como ejercicio de reflexión puede contribuir a miradas más densas sobre las acciones humanas. Las ciencias sociales muchas veces dejan de lado la fuerza de los afectos para comprender la energía que mueve la construcción y puesta en escena de visiones de mundo en torno a la muerte. En este sentido retomo las palabras de Paolo Vignolo $(2015$, p. 13) cuando se pregunta sobre el lugar 
simbólico del cementerio. Es "¿un museo al aire libre, un refugio del caos citadino, una prisión de almas o un lugar de memoria de las tragedias nacionales?". Plantea la necesidad de pensarlo como un "gran archivo afectivo, al mismo tiempo el arché con el cual nos relacionamos con nuestros antepasados y la ciudad jerárquica del arconte. Nos recuerda que quien controla la necropolís también comanda la polis. Aunque de todas maneras siempre llega el momento en que hay que hacer cuentas con las historias de vida de la ciudad de los muertos. Y es precisamente la carga afectiva que se agita en este archivo colectivo que es el cementerio, lo que nos obliga a repensar la forma con que manejamos nuestros tráficos con el más allá" (Vignolo, 2015, p. 13).

Esos instantes de experiencias frente a la muerte configuran un sustrato cultural y político de las maneras a partir de las cuales podemos enfrentarla, comprenderla y sobrellevarla. Las experiencias vividas, las formas de transitar los duelos, pero sobre todo la presencia de los muertos en la vida infantil, construyen una subjetividad particular en torno a la manera en que conocemos que es morir y que se hace con la muerte. Por otro lado, implica una cierta sociabilidad que genera prácticas y representaciones en torno a los modos en que cuidamos, visitamos y recordamos a nuestros antepasados.

En este texto me interesa mirar a través de las alteridades mínimas para comprender las alteridades distantes. ${ }^{1}$ Si en la intimidad del panteón mi abuela intentaba dejarme el legado del cuidado de los muertos es porque esta misma sociabilidad le había sido transmitida antes a ella. De esta forma utilizo estas herramientas para observar etnográficamente las maneras y modos con los cuales los familiares de desaparecidos construyen la relación con sus muertos ¿Cómo se transita el duelo cuando no hay cuerpo, ni tumba? ¿Qué elementos se pueden distinguir en los procesos donde la muerte debe ser imaginada? ¿Qué rituales y acciones se ponen en juego para el cuidado de esos muertos?

En la primera parte, trazaré los elementos centrales para comprender la desaparición dentro de la noción de muerte. A continuación, estableceré nexos entre imagen, duelo y desaparición. Para esto, observaré el espacio que ocupa la fotografía frente a la desaparición de personas, ocupando la huella de esa ausencia y un lugar de memoria (Nora, 1997) singular para el duelo. Finalmente, me detendré en la etnografía de las acciones, rituales y prácticas en torno al cuidado de los muertos frente a la falta del cuerpo. Para esto, describiré el acervo fotográfico denominado "Registro de extremistas"2 localizado en el Archivo Provincial de la Memoria de Córdoba. Se trata de un espacio autónomo y autárquico del Estado, creado por Ley 9286 en marzo de 2006. El órgano de gobierno del Archivo es la Comisión Provincial de la Memoria integrada por representantes de los organismos de Derechos Humanos de la Ciudad, la Universidad y los Poderes del Estado.

El lugar ocupado espacialmente por el Archivo fue entre 1974 y 1983 un Centro Clandestino de Detención (en adelante mencionado como CCD) del Departamento de Inteligencia de la Policía de la Provincia de Córdoba (en adelante identificado como D2),

1 Uso aquí las nociones de alteridad mínima y distante de Peirano (1995).

2 Archivo Provincial de la Memoria de Córdoba (en adelante APM-Córdoba). Fondo de la Policía de la Provincia de Córdoba. Serie Libro Registro de Extremistas. (1971-1977). 
localizado en pleno centro de la ciudad, frente a la Catedral y a escasos pasos de la Plaza San Martín. Esta dependencia policial comenzó sus acciones ilegales antes de la dictadura militar argentina (1976-1983) ejerciendo un "laboratorio" de la represión clandestina que luego se ejecutaría a lo largo del país con la llegada del gobierno de facto. Durante este período de tiempo, la violencia ejercida por el Estado provincial registró numerosas detenciones ilegales, aplicación de tormentos a los detenidos y asesinatos y desapariciones. El D2 asesinó y desapareció entre 1974 y 1979, 91 personas, de las cuales 52 hombres y mujeres fueron asesinados y/o desaparecidos entre los años 1974 y $1975 .{ }^{3}$

En este archivo, me detendré en el análisis de cuatro historias de hijos de desaparecidos relevadas a partir del registro etnográfico de la relación entre estos hijos y las acciones llevadas adelante por este sitio de memoria. ${ }^{4} \mathrm{Me}$ interesa la mirada de los hijos de desaparecidos, ya que ellos tuvieron pocas o ninguna oportunidad de ver a sus padres en los momentos previos al desenlace de su muerte. En muchos casos, no pudieron construir una imagen con vida sino sólo y a través de la fotografía familiar y en algunos casos extremos a partir de las fotografías policiales.

\section{La muerte en contextos de represión}

Sabemos que la figura del desaparecido no es solamente una noción jurídica - para enunciar un acto ejecutado por el Terrorismo de Estado - sino también una noción proveedora de material específico para la conformación de un sistema simbólico donde predominan elementos tradicionalmente asociados a la liturgia frente a la muerte, aunque estos no sean reconocidos como tales e incluso negados. En lugar de marcar y habilitar el pasaje del mundo de los vivos al mundo de los muertos, los rituales puestos en escena transforman la ausencia del cuerpo en un capital de fuerza política.

En los procesos "normales" de muerte, donde el cuerpo es el locus de la sepultura, el cementerio es el espacio que divide el mundo de los vivos del mundo de los muertos. Se constituye como un lugar fundado en lógicas propias, donde las marcas del parentesco, de filiación, de clase social y las de pertenencia a grupos específicos aparecen como señales y mojones que indican quién es la persona que está allí sepultada. La marca de la sepultura funciona como un operador que integra en una estructura meta-histórica al grupo social desgarrado por

\footnotetext{
3 Para mayores datos sobre el período puede consultarse el libro Nunca Más. Informe de la Comisión Nacional sobre la Desaparición de Personas. Buenos Aires: EUDEBA. 1987 y sobre el accionar del D2, APM-Córdoba. Marcas que no se borran. Cartografías de la memoria en homenaje a las mujeres y los hombres desaparecidos y asesinados por el D2. Ediciones del Pasaje: Córdoba. 2011.

4 Durante los años 2006-2015 dirigí el Archivo Provincial de la Memoria de Córdoba. En dicho espacio, desde su creación generé diversas acciones de gestión y paralelamente desarrollé mi trabajo de investigación en CONICET. Una de las líneas de indagación estuvo dirigida a relevar y analizar las series documentales relativas a la Policía de la Provincia de Córdoba, específicamente aquellas que daban cuenta del registro fotográfico de personas desaparecidas por motivos políticos. En relación a las historias que son analizadas en este texto, el material fue recolectado mediante entrevistas y charlas con los hijos de desaparecidos, notas de campo, análisis de material audiovisual y diarios locales dónde fueron registradas dichas desapariciones. Entrevistas. Carolina Llorens. APMCórdoba. Colección HIJOS de detenidos desaparecidos. Área de Historia Oral y Audiovisual. Disponible en: $<$ http://apm.gov.ar/apm-historia-oral/>. Acceso en: 18 de abril de 2017 y Entrevistas. Natalia Colón. Colección HIJOS de detenidos desaparecidos. APM-Córdoba. Área de Historia Oral y Audiovisual. Disponible en: < http:// apm.gov.ar/apm-historia-oral/>. Acceso en: 18 de abril de 2017.
} 
la muerte (Faeta, 1993) y recrea en un nuevo espacio las relaciones de parentesco, las redes sociales y culturales transformadas por la muerte. ${ }^{5}$

Con la falta del cuerpo, provocado por la violencia del Estado con la desaparición ¿Dónde se localiza la muerte? ¿Cómo se transporta la fuerza emocional ${ }^{6}$ del luto que normalmente se genera delante de la sepultura de un hijo, un padre, un hermano muerto? ¿Qué espacios son recreados para dar cuenta de esa ruptura? ¿Cómo son rearmadas y construidas las clasificaciones sobre la muerte? ¿Cómo es caracterizada y expresada para que esos muertos no se transformen en fantasmas?

Durante mi trabajo de campo en Jujuy observando las experiencias de los familiares de desaparecidos en los contextos locales de producción de memorias, una vecina de la localidad de Guerrero, que vivía al lado de lo que fue el Centro Clandestino de Detención Guerrero, nos interpeló: "miren señoritas, acá los muertos andan como alma en pena... a los que mataron acá. Sus familiares no tienen dónde llorarlos y nadie los llora acá. No tienen dónde llevarle una flor, dónde prenderle una vela... Yo a veces los siento llorar...".7

Como hecho social, la muerte genera una modificación en el tiempo y en el espacio del grupo social afectado. Estos cambios tienen como referente principal las obligaciones, los comportamientos, los ritos religiosos o seculares que por un determinado período provocan una intensificación de los sentimientos, emociones y estados corporales. La muerte es "representada y sentida" en un proceso cultural que lleva tiempo y elaboración. Es un período liminal, no de destrucción, sino de transición a un nuevo estado, donde el cuerpo, el alma del muerto y las acciones de los sobrevivientes conforman elementos esenciales del sistema de creencias y prácticas en torno a la muerte. En este conjunto simbólico de recursos, el estado del cuerpo es un modelo del estado del alma, el muerto se separa de los vivos como sus parientes se separan de la sociedad a través del luto. ${ }^{8}$ La desaparición provoca una acción inversa a la concentración de espacio-tiempo requerida socialmente para enfrentar la muerte. Los familiares de desaparecidos por muchos años esperan, buscan y abren espacios. Por este motivo las solidaridades, las expresiones de ayuda y las solemnidades del luto se expresan mucho más diluidas, a veces en posturas políticas, otras en gestos efímeros como una pregunta o un simple comentario, pero muchas veces con un gran silencio por parte de la comunidad de pertenencia. En contraposición, la intensidad y profundidad del espacio-tiempo creado por la muerte quiebra la rutina, la normalidad y define ciclos marcados con un inicio y un fin. Se

5 Teniendo como base teórica los estudios de Victor Turner sobre la "liminaridad", Allué afirma que en los procesos de muerte donde el cuerpo está presente los "ceremoniales más complejos se llevan a cabo en la fase de agregación, cuando el cadáver se separa oficialmente de su red social, la fase más rica simbólicamente es la de margen porque incorpora el concepto de liminaridad [...][en el cuál] los seres en transición se encuentran "al margen del margen" flotando sin relación a los puntos fijos reconocidos del espacio-tiempo de la clasificación estructural. Esa secuencia va ligada a ideas de contaminación y tabú que se reflejan en las conductas de evitación en relación al cadáver, al lugar donde se encuentra y a los objetos que le pertenecieron. Es una etapa de suspensión temporal que finaliza con la ceremonia de evacuación" (Allué, 1998, p. 75). Son estos momentos de tiempo-espacio los que se modifican en relación a los pasos del duelo en los casos de desaparición de persona, por la ausencia del cadáver inversamente a este proceso los objetos del desaparecido y su foto pasan a imprimir los espacios de recuerdo, no de tabú ni distancia sino de preservación como única huella de su existencia.

6 Uso acá la noción fuerza emocional en el sentido establecido por Renato Rosaldo (2000, p. 23).

7 Registro de campo personal realizado durante el trabajo de campo en Guerrero (Jujuy). 25 de julio de 2003. Charla con vecina del lugar.

8 Para un análisis sobre la construcción de sistemas simbólicos en torno a la muerte puede consultarse la clásica obra de Hertz (1990). 
pueden distinguir tres momentos que ponen en suspenso la vida de los familiares del muerto: el momento de la muerte; el tiempo de luto/expresión de la compasión y el momento de la interiorización/duelo.

En este período la idea de compasión se torna central, en tanto que a partir de ella se distingue a los hombres y mujeres que sufren de aquéllos que no sufren, en relación a la expresión obligatoria del sufrimiento, distinguidos por las expresiones exteriores del cuerpo (uso del color negro) y sus marcas en la expresión de los sentimientos (lágrimas, gritos, silencio, tristeza, dolor). Estas actúan como los elementos esenciales de distinción entre aquéllos afectados por la muerte de un familiar o ser querido y aquéllos que acompañan, calman y consuelan a los afectados. La relación entre el sufrimiento y la compasión está especificada por la naturaleza de los lazos preexistentes, que ligan al ser sufriente con aquél que toma conocimiento de ese sufrimiento. Estos lazos permiten ordenar las obligaciones de asistencia y consuelo a partir de clasificaciones de pertenencia o no al grupo.

La no-existencia de un momento único de dolor y de las obligaciones morales sobre el muerto, asociados al desconocimiento sobre los modos del morir, constituyen una nueva figura: la privación de la muerte (Schmucler, 1996, p. 11) o una muerte desatendida (Panizo, 2010, p. 19). Cómo ya analicé hace algunos años, desde mi punto de vista la categoría desaparecido representa una muerte inconclusa, en su triple condición: la falta de un cuerpo, la falta de un momento de duelo y la de una sepultura. (Da Silva Catela, 2001, p. 121). Sin embargo, si a ésta triple falta, la miramos desde otro lado, no de la ausencia sino de la producción de acciones, permite descubrir formas instituidas de canalizar el dolor y de creación de rituales alternativos de duelo, lugares de recuerdo y conmemoración. Si pensamos el luto como representación dramática, Allué (1998, p. 75), plantea la necesidad de reconocer cuales son los "elementos que permitan mostrar el dolor a través de los símbolos del luto favoreciendo la catarsis, la expresión emocional del sentimiento de pérdida". Vale preguntarse entonces ¿dónde se construye esta representación en el caso de la desaparición de personas? Marchas, rituales colectivos de recuerdo, acciones teatrales, música, espacios de judiciales, exposiciones en los sitios de memoria, constituyen algunos de esos lugares de representación que permiten una variedad significativa de formas de poner en evidencia esas desapariciones-muertes y proveer de espacios de luto.

Voy a detenerme en un soporte en particular, la fotografía, sus usos y rituales como uno de esos espacios a ser observados y analizados. La imagen como soporte que registra lo que ya desapareció, gana fuerza de evidencia cuando aquello que imprimió fue un retrato, una mirada, un rostro de personas desaparecidas. Esa doble desaparición, la del momento del registro visual y el de la persona que ha sido revelada por la imagen, permite pensar a la fotografía como una metáfora de las acciones que desde el presente y a través del trabajo político hace la memoria. De esta manera las pienso como un espacio de duelo, ya que la fotografía "entraña una irrupción, una fragmentación temporal, así como una demarcación espacial que lleva a la significación mediante la articulación de todo aquello que ha quedado dentro de la imagen como constitutivo de una dinámica interna de sentido" (Hernández, 2015, p. 156). Sentidos que son activados desde el presente, creando nuevos tiempos y transformando a esas pequeñas 
imágenes en lugares de memoria pobladas de materialidad, funcionalidades y significados que pueden ser activados una y otra vez. Transformadas en objeto de conmemoración y de rituales.

\section{Imagen, duelo y desaparición}

La fotografía es nuestro exorcismo. La sociedad primitiva tenía sus máscaras, la sociedad burguesa sus espejos, nosotros tenemos nuestras imágenes.

(Baudrillard, 1997, p. 194]

Las fotografías de los desaparecidos y su utilización en diversas esferas constituyen una de las principales formas de representación de su existencia tanto como de su muerte. No sólo han logrado representarla, sino que en la misma acción han creado un fuerte referente icónico para la denuncia, la demostración de los afectos y la memoria. Estas acciones se construyen tanto en el ámbito doméstico como en el público; tanto en los pequeños pueblos como en el contexto internacional. La foto de un rostro, en blanco y negro, utilizada en una marcha, portada sobre el cuerpo de una Madre de Plaza de Mayo, colgada en una plaza, estampada en una bandera argentina, impresa en un Diario, raramente merece la pregunta de ¿quiénes son? o ¿qué significan? Hay un sustrato cultural y político compartido y establecido que genera un lazo entre la memoria de los desaparecidos, su presencia en el espacio público y las imagen de sus rostros en fotos carnet en blanco y negro (Da Silva Catela, 2009). En este sentido tanto la percepción como la representación, de la imagen fotográfica ligada a la violencia, constituyen actos sociales en torno a la muerte. Inicialmente hay que decir que el concepto de imagen no puede separarse aquí del concepto de cuerpo, ya sea el cuerpo de los sobrevivientes ligado a la tortura en los CCD o el de los desaparecidos. No sólo representa al cuerpo ausente o fragmentado por la violencia, sino también, al modelo de cuerpo sufriente de la humanidad como un todo.

Todos sabemos que la fotografía de los muertos en el interior de las casas funciona como una metonimia de estas personas ausentes, que al igual que el gesto de mi abuela besando la foto de sus muertos, esto se repite una y otra vez en muchas experiencias similares. El uso de la fotografía como instrumento recordatorio de un "afín" ausente recrea, simboliza y recupera una presencia que establece nexos entre la vida y la muerte, lo explicable y lo inexplicable, lo individual y lo colectivo. Las fotos "vivifican". Como una metonimia, encierran una parte del referente para totalizar un sistema de significados. La fotografía de personas y con mayor fuerza los retratos y su mirada, transportan formas de comunicación y diálogo. Frente a las fotos de seres queridos muertos, las personas "conversan", les comunican novedades, les piden consejos, los saludan, les colocan flores, los acarician. Este acto de tocar a los muertos tocando su retrato, es una de las prácticas de socialización más comunes, que como relaté al principio yo aprendí de mi abuela. En el caso de los desaparecidos, la foto funciona como una fuente de recreación de lazos sociales y parentales que han cesado con la ausencia física de 
ellos y fundamentalmente con la ausencia de sus cuerpos.

La relación entre fotografía que fija un pasado y memoria que trabaja desde el presente la podemos pensar desde la metáfora utilizada por Halbwachs (1990) "retocar el retrato". Es justamente esta acción de "retocar" donde la memoria imprime su trabajo. Desde el presente, esas imágenes que llegan del pasado se recubren y ganan nuevos significados a partir de las relaciones sociales, de las nuevas preguntas y de las identidades que las interpelan. Ahora bien, retocar un retrato implica, entre otras cuestiones, una reconstrucción que no se realiza al azar, sino a partir de líneas ya demarcadas por el recuerdo individual, colectivo y por los procesos de transmisión presentes en cada comunidad. Como bien afirma Jean Baudrillard,

la foto es una imagen en tiempo real. Ella conserva el momento del negativo, el suspenso del negativo, ese ligero desfasaje que permite existir, antes que el mundo [...] desaparezca en la imagen, dónde lo real ya desapareció. La foto preserva el momento de la desaparición y por lo tanto de lo real como una vida anterior (Baudrillard, 1997, p. 195).

Las imágenes tornan visible lo que la desaparición quiso borrar. Desde su carácter indicial, arrastran al presente la huella de lo que fue. En palabras de Roland Barthes, lo plasmado por la cámara estuvo allí para que la imagen fotográfica se produzca, sin embargo, "la fotografía no rememora el pasado (no hay nada de proustiano en una foto). El efecto que produce en mí no es la restitución de lo abolido (por el tiempo, por la distancia), sino el testimonio de que lo que veo ha sido" (2012, p. 128).

Cuando hablamos de la desaparición y de la tortura, la representatividad de la imagen entra en cuestión. Como dice Victoria Langland

quedan fotos de lo que hubo antes, pero no se pudo fotografiar una desaparición en sí. No hay fotos de los vuelos de la muerte. No hay fotos del acto de tortura [...] En general podemos decir que no existe una fotografía que resuma, o pueda representar, la atrocidad masiva del terrorismo de Estado en el Cono Sur (2005, p. 88).

Pero si hay fotos que evocan la muerte, que reflejan esas últimas miradas dentro de los centros clandestinos de detención, como las fotos robadas por Víctor Basterra, de la Escuela de Mecánica de la Armada (ESMA), ${ }^{9}$ que muestran los rostros agotados, golpeados, humillados, en algún momento antes de transitar hacia la muerte. Entre esas imágenes que evocan la

9 Víctor Basterra fue detenido-desaparecido en la ESMA entre los años 1979-1983. En dicho Centro Clandestino de Detención localizado en la ciudad de Buenos Aires, fue obligado por las fuerzas represivas a realizar fotografías de detenidos desaparecidos y de los propios militares para la falsificación de documentos públicos. Durante mucho tiempo Basterra fue "guardando" negativos que pudo sacar fuera del centro clandestino una vez que fue liberado. Ver: <http://www. desaparecidos.org/nuncamas/web/investig/basterra/basterra_01.htm>. Parte de esas fotografías actualmente se encuentran expuestas en el Sitio de Memoria de la ex ESMA. Un análisis de ésta serie fotográfica y el debate sobre el sitio de memoria de la ex ESMA, puede consultarse en García (2009). 
muerte, están las que pertenecen al acervo fotográfico denominado por la policía de Córdoba Registro de Extremistas. Esta serie se compone de 150.000 negativos de fotos policiales que comprenden un período de tiempo extenso (1964-1989), que incluyen a ciudadanos fotografiados para fichas policiales por innúmeras causas. Del total de ese acervo unas 10.000 imágenes corresponden a detenidos por causas políticas, las que han quedado asentadas en el libro de guardia policial encabezado por el nombre de Registro de Extremistas En este se detallan la fecha de detención, el nombre y el apellido de la persona detenida, el número de negativo fotográfico y en algunos casos observaciones de la militancia política o del motivo de su deceso.

La historia del hallazgo de este acervo fotográfico comienza con una denuncia anónima que determinaba el lugar dónde podía ser encontrado. Los agentes del Tribunal Federal III, en el marco de los juicios por la verdad a fines de los años noventa realizaron un allanamiento que permitió rescatar las cajas de fotografía. Desde el año 2009, se encuentra en custodia del Archivo Provincial de la Memoria de Córdoba (APM). Esta institución es la encargada de digitalizar los negativos y realizar la búsqueda de las imágenes, que son solicitadas por los familiares de desaparecidos, la justicia, los abogados querellantes, entre otros. El procedimiento de revelación de estas fotografías tiene una secuencia de acciones. En primera instancia los integrantes del área Archivo y Documentación, buscan la imagen, la digitalizan y la copian en papel. A continuación el área Investigación realiza el acto de entrega al familiar o al propio preso político que quedó registrado bajo la lente policial. Es necesario decir, que este acervo se caracteriza entre otras cuestiones, por mostrar la clandestinidad de la acción policial, ya que al revelar las imágenes aparecen "los márgenes", lo que no debería haber quedado registrado: represores con vendas en la mano, prisioneros vendados, rostros de los secuestradores, lugares y áreas de detención, acciones cotidianas de la policía en un centro clandestino de detención.

La fuerza de evocación de estas imágenes radica en el retrato policial del detenidodesaparecido, días o meses antes de su muerte. Muchas de ellas son la última o única imagen con la que cuenta el familiar. El efecto perturbador en estas fotografías son las miradas que se encuentran. Dos miradas, opuestas, que allí se tornaron visibles. La del fotógrafo que gatillaba su cámara frente a detenidos golpeados y torturados en un centro clandestino de detención y la de estos hombres y mujeres que observan, a través de la cámara, al Estado represor que los catalogaba como extremistas, los torturaba y asesinaba. En este acto de mirar se ponían en juego alteridades irreconciliables. La mirada de los secuestrados que era "liberada" por un instante para registrar su rostro. Alli se encontraban con la lente fotográfica y en el acto siguiente, eran nuevamente vendados, para que sus ojos "eviten" la mirada del torturador.

A partir de estas fotografías, que nos ofrecen un poco de la aberrante verdad de los centros clandestinos de detención, fragmentos visuales sobre el horror de lo sucedido, "instantes de verdad" (2004, p. 57), al decir de Didi-Huberman, se analizarán cuatro historias de la relación de hijos de desaparecidos con la imagen de sus padres. Para esto es necesario comprender el significado que adquiere la entrega de las fotos por parte de una institución del Estado. Observarlas como ceremonias restauradoras de los afectos y sentimientos quebrados, perturbados por tantos años de desconocimiento sobre las formas de morir que tuvieron sus 
padres y sobre el silencio que pesa en relación al destino de esos cuerpos. Ante la ausencia y la imposibilidad de saber sobre la intensidad del sufrimiento al que fueron sometidos sus seres queridos, la fotografía actúa como reparadora y como un pequeño reservorio de rituales de muerte.

\section{Gustavo}

Gustavo vive en España. Es hijo de Jorge Alberto Germain, desaparecido el 02 de junio de 1976. Jorge era militante del Partido Revolucionario de los Trabajadores-Ejército Revolucionario del Pueblo (PRT-ERP) y trabajador de Yacimientos Petrolíferos Fiscales (YPF).

Durante el año 2014, Gustavo comenzó una tarea de reconstrucción del paso de su papá por el Centro Clandestino de Detención denominado Puesto Caminero de Pilar, ${ }^{10}$ realizó visitas y entró en contacto con el APM. Desde el área de investigación se realizó una búsqueda sobre los registros documentales de su padre. Entre la documentación entregada, se encontraba la fotografía Jorge Alberto Germain en el Registro de Extremistas (Ver Figura 1).

Figura 1: Foto de José Alberto Germain

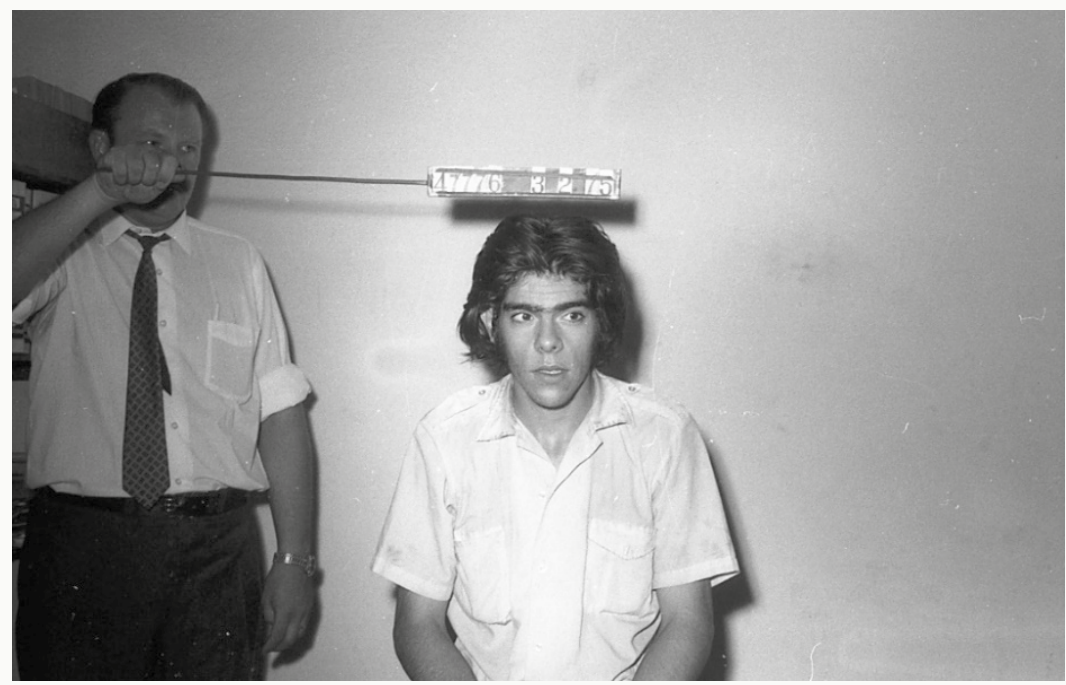

Fuente: Archivo Provincial de la Memoria - Córdoba. Registro de Extremistas

En respuesta al envió de la documentación, Gustavo escribió la siguiente reflexión en un mail remitido a la persona encargada de la entrega de los documentos en el Archivo Provincial de la Memoria:

10 Para mayor información sobre los Centros Clandestinos de Detención en Córdoba ver: < $\underline{\text { http://apm.gov.ar/ }}$ periplosdememorias/materiales/1-1/AportesReflexion/CatalogoCCD_Cba/centros_clandestinos_cordoba_ catalogo.jpg.pdf>. 
Gracias Fabiola, todavía no salgo de la conmoción... Estoy mirando los papeles que me diste y ésta entrada del 03/02/75 registrada en el folio $4 \ldots$

Se lo ve como que sabe de qué va el tema. Ya se lo habían llevado en el 74, imagino que se presentaría si lo soltarían, o si todo acabaría ahí...

Por otro lado, son las fotos más nítidas que tengo de mi viejo y eso me hace mucha ilusión.

Estos días lo pensé mucho, siempre lo pienso...ya te imaginas...es que lo veo tan crío... Por lo que se, en esa época eran jóvenes, se sentían inmortales, pero creo que en el fondo siempre tenían la duda ¿no?

Sí que nos parecemos bastante y los que le conocieron cuando me ven alucinan. Bueno de todas maneras te estoy muy agradecido, porque puedo mirarle a los ojos... Que nunca había tenido esa posibilidad. Te mando un texto cortito prueba de lo que me generó y de cómo estoy pensando en mi Viejo querido:

\section{Autorretrato}

Soy plenamente consciente de la redondez de la tierra, de la amplitud del universo, de la vida que subyace bajo el suelo de los bosques, del color de los olvidados, de la existencia de los huesos de mi padre en algún páramo perdido, de la brisa que me estremece en este momento. Soy el hijo de la resistencia, soy dolor, soy amor, soy y soy huella.

Yo siempre pienso en él. Cada día. Pero a veces lo siento muy fuerte como si estuviera a mi lado. ${ }^{11}$

Para Gustavo, la imagen de su papá retratado por la cámara policial pasa a adquirir un nuevo sentido. Produce reflexión, empatía, preguntas, respuestas, poesía. Le permite conectarse con la muerte, pero también con la cercanía de un cuerpo que no se puede distanciar porque no está. Puede mirarlo a los ojos y pensarse en ese acto. Como lucidamente apunta Hans Belting,

la evidencia de la vida, con la que deseamos encontrarnos en la imagen, depende de que entre la imagen y su espectador prevalezca una simetría en la experiencia y en la época, para que la mirada de la vida en la imagen sea capaz de convencer. En el punto donde la vida y la muerte se interceptan, la imagen muestra un aura vital específica. No obstante, sólo la muerte proporciona a nuestra memoria el significado fundamental que alguna vez dio vida a las imágenes (2009, p. 231).

Las instantáneas con las que interrumpimos por un momento el incesante flujo del tiempo, son imágenes fugaces e intercambiables. El recuerdo de uno mismo, "soy el hijo de

\footnotetext{
${ }^{11}$ APM-Córdoba. Área de Investigación. E-mail enviado por Gustavo Germain a Fabiola Heredia, trabajadora del APM/Área de Investigación, en 16 de julio de 2014.
} 
la resistencia, soy dolor, soy amor, soy y soy huella" en el escrito de Gustavo, es un ejercicio reflexivo y no una superación de la muerte inconclusa de su padre. Pero esa fotografía sirve como espacio de duelo, vuelve a contextualizar la muerte, permite pensarla y darle sentido para comenzar a separar el mundo de los vivos de los muertos. Nombrar la muerte, volver a encastrarla en un sistema de rituales que le permite evocar el nombre del padre y conjurar el olvido.

\section{Carolina}

Carolina es hija de Sebastián Llorens y Diana Traiy, desaparecidos en Buenos Aires en diciembre de 1975, ambos militantes del Partido Revolucionario de los Trabajadores (PRT). En octubre del 2012 los restos de Sebastián y Diana aparecen... salen a la luz en el lugar menos pensado. A orillas del río La Matanza, al borde de la avenida La Noria, en la frontera del barrio Sarmiento... en Buenos Aires. Un lugar insólito, no sólo porque no había referencias en relación a enterramientos clandestinos, sino porque allí se juntaron dos acciones del azar. La primera. Que un vecino buscando tierra para su casa se encontrará con bolsas negras llenas de huesos y decidiera realizar una denuncia. La segunda. En ese Barrio, Carolina, que vive en Córdoba, realizaba un trabajo territorial político junto al SERCUPO, el movimiento de campesinos e inmigrantes que habitan ese pedazo de suelo. Fue justamente un inmigrante paraguayo, que buscaba tierra para hacer su casa, quien encontró los huesos, que luego serían identificados por el Equipo de Antropología Forense como los restos de los papás de Carolina.

Carolina decidió que debía hacer un ritual con los restos de sus padres y eligió la Universidad Nacional de Córdoba para velarlos. Nos pidió a los trabajadores del APM, que la ayudáramos a pensar cómo hacerlo, ya que no era nada usual ni el lugar ni la situación. Desde el Archivo Provincial de la Memoria acompañamos el proceso de restitución de los restos óseos de los padres de Carolina. Planificamos y organizamos los rituales que llevaron a velar los restos en la sede de la Universidad Nacional de Córdoba (UNC). Este proceso que llevó dos meses de trabajo conjunto, luego de numerosas reuniones, charlas, entrevistas y decisiones en torno a las acciones para llevar adelante este particular proceso de velar restos desaparecidos y "restituidos", cuarenta años después del asesinato. Los rituales que se desarrollaron durante todo un día en la UNC, contaron con la exposición de obras de arte realizadas por sus padres, música, proyección de fotografías, plantación de árboles y peregrinación frente a las urnas funerarias. Parte de este proceso quedó registrado en la publicación Diana y Sebastián. ${ }^{12}$

En ese contexto de elaboración colectiva de un ritual de muerte, se propusieron diversas acciones para pensar una conmemoración donde el duelo fuese posible. Donde se pudiera acompañar a los familiares cuarenta años después de la muerte de Sebastián y Diana, en un espacio particular como era la Universidad. El ritual de recepción de los restos y de despedida tuvo varias etapas y momentos. Primero se realizó en el lugar donde fueron

12 APM-Córdoba. Diana y Sebastián. Ediciones del Pasaje: 2013. 
encontrados, junto a los pobladores del barrio. Luego fueron traídos a Córdoba y velados en un pequeño teatro de la Universidad. Allí hubo música, velas, flores, producciones de arte, pinturas de Diana y filmaciones de Sebastián, se plantaron árboles con sus nombres, circuló la palabra, se gritó presentes! Las fotos del Registro de Extremistas ocuparon un lugar central, tanto en el ritual como en la producción de un álbum de recuerdo denominado Diana y Sebastián. ${ }^{13}$ En esta conmemoración, lo significativo fue la manera como estas imágenes provenientes de la acción policial y de las fichas de persecución, fueron resignificadas. En especial, la imagen de su mamá adquirió un poder de representación inusitado. Carolina había escuchado de parte de sus familiares y amigos de su mamá, la descripción una y otra vez, de una mujer sonriente, con largas trenzas negras. Pero Carolina nunca vio a su mamá con esas trenzas que forjaban la identidad de su rostro. Hasta el momento que se reveló la imagen del Registro de Extremistas (ver Figura 2). Allí apareció la foto policial, donde Diana fue capturada como esa chica de largas trenzas.

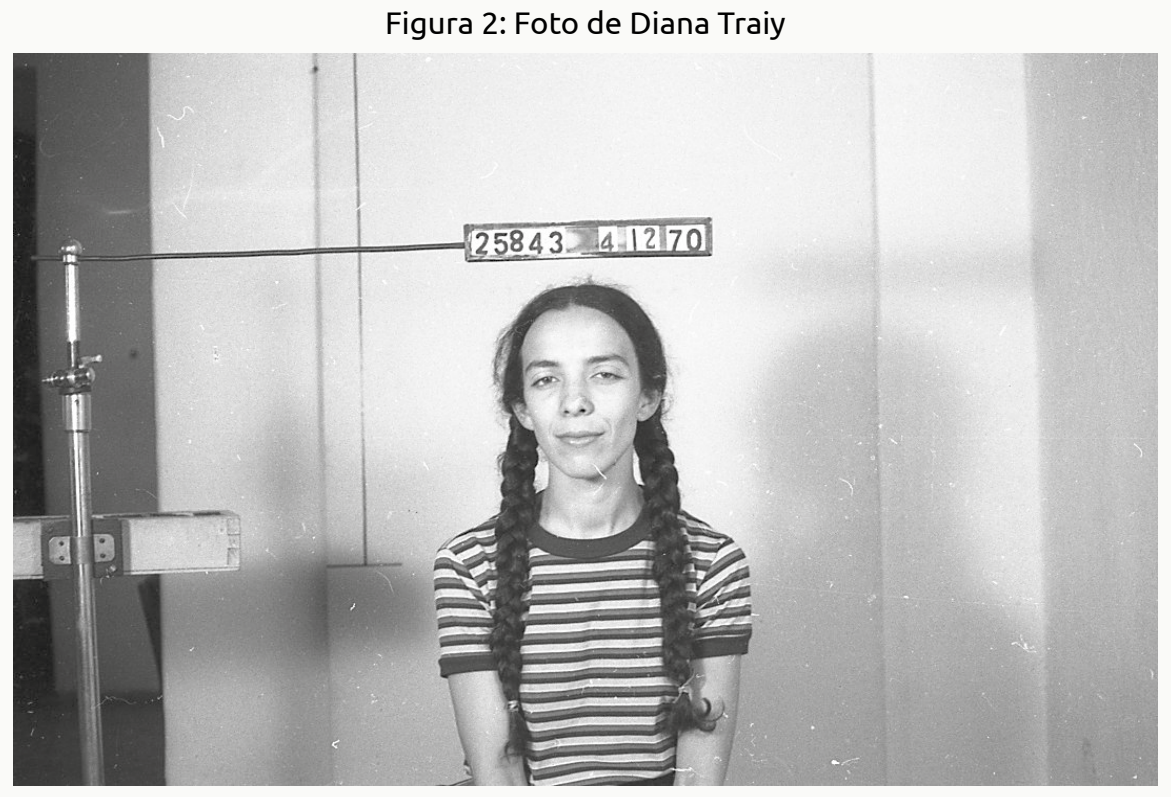

Fuente: Registro de Extremistas. Archivo Provincial de la Memoria

A diferencia de otros hijos, donde la foto pasa a ubicarse en el espacio del cuerpo que no está, que se busca, que se espera. Imágenes que ocupan el lugar de lo sagrado y que permiten instancias de duelo, para Carolina, estos soportes de memoria pasaron a constituir un juego de espejos. Pudo reflejar en ellas la imagen por muchos años construida en los relatos familiares, pero también se atrevió a modificarlas, a "jugar" como un territorio estético donde decir algo más en la instancia de recuperación y restitución de los restos de sus padres. Las imágenes, usadas originalmente por la policía como testimonio de su accionar represivo a los militantes políticos, pasaron a ser parte del ritual frente a la restitución de los restos. En contraposición a los huesos, fueron la evidencia de la vida. Las trenzas de su mamá resignificadas con un tejido

13 Idem. 
realizado por sus propias manos como fondo y la poesía del padre escrita sobre la imagen del Registro de Extremistas. Recortar la imagen, escribir sobre la fotografía, dejar nuevas marcas, sentidos superpuestos fue poner en ejercicio el trabajo de la memoria desde un presente lleno de vida, donde el duelo fue posible y permitió proyectar hacia un futuro nuevas imágenes de Diana y Sebastián ${ }^{14}$ (ver Figura 3).

Figura 3: Fotos del Registro de Extremista modificadas y utilizadas en las conmemoraciones de restitución de los restos de Diana y Sebastián
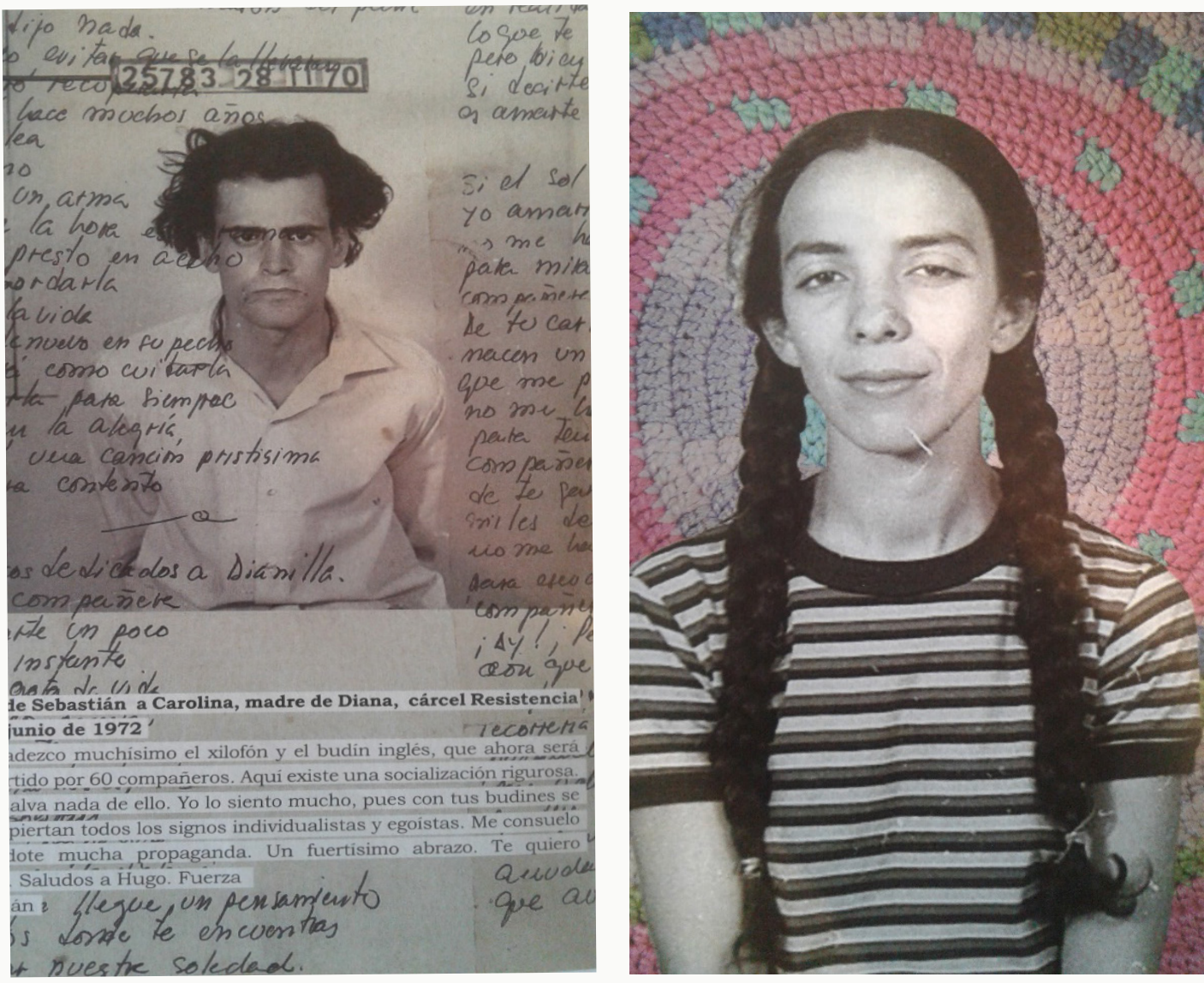

Fuente: Archivo Provincial de la Memoria de Córdoba. Diana y Sebastián. Córdoba: Ediciones del Pasaje, p. 15-18, 2013.

Ana

Ana es hija de Humberto Cordero desaparecido el 24 de septiembre de 1976, militante del Partido Comunista. Fue secuestrado y desaparecido en el centro clandestino de detención y exterminio La Perla. Dentro de la documentación que obraba en custodia del APM, estaba la fotografía de Humberto en una detención previa a su desaparición. Una imagen del año 1974, que sus hijos desconocían.

Varios integrantes de la familia vinieron a recibir "los papeles". Como en una ceremonia conmemorativa de reencuentro, tomaron mate en una de las oficinas, mientras se terminaban

14 Idem. 
de firmar, sellar y presentar los documentos que constituian el informe sobre la desaparición de Humberto Cordero. Entre ellos estaba la foto del Registro de Extremistas. Ana acompañaba a su hermana.

La encargada de entregar la documentación de repente interrumpe la charla familiar y los llama para explicarle el origen de cada documento que acompaña el informe. Fechas, significado de cada firma, origen de la documentación. La familia en silencio escucha cada detalle. De repente comienza la descripción sobre las fotografías. Una de las hijas de Humberto, mira fijamente la documentación y se detiene en las fotografías. Ana las observa y grita: "iique te hicieron papito, que te hicieron!!!." Comienza a llorar desconsoladamente. Luego lleva la imagen hacia su cara y se seca las lágrimas sobre el rostro de su papá. ${ }^{15}$

En la foto se lo ve a Humberto con una camisa blanca ensangrentada (ver Figura 4). Sus ojos miran fijamente a la cámara. Al costado aparece un brazo que sostiene el cartel con la fecha de detención. Esa imagen construye en las manos de su hija Ana, un tiempo circular, real e inexistente a la vez, aquel tiempo que representa el momento previo a la desaparición. Ana toma conciencia de esto y por primera vez siente la muerte de su padre entre sus manos. Las lágrimas, el espanto y el dolor, la acompañan por un largo instante. Necesita salir de la habitación en la que se encuentra. Parada en una esquina del patio del APM, no quiere hablar con nadie. Una vez recuperada de ese momento de lágrimas, agradece y vuelve a besar la foto de su padre.

Figura 4: Foto de Humberto Cordero

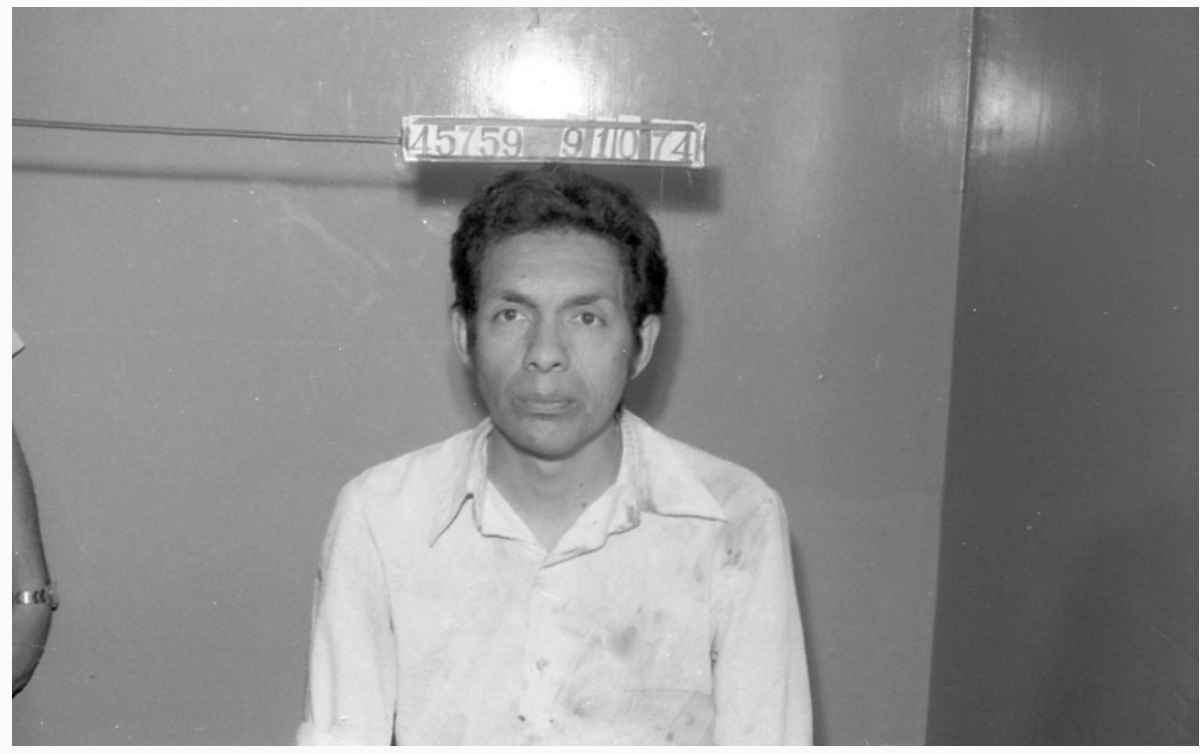

Fuente: Registro de Extremistas. Archivo Provincial de la Memoria

\footnotetext{
${ }^{15}$ APM-Córdoba. Descripción entrega de documentación, oficina del Área de Investigación. Registro de campo propio. Observación participante, junio de 2013.
} 
De manera inversa a las buenas muertes, la "mala muerte" aquella relativa a la desaparición genera un proceso de sentimientos de subjetivación del dolor a cuarenta años de los hechos. Cómo apunta Mauro Koury, la muerte

representando la impotencia y el fracaso humano revela también la fragmentación de las relaciones sociales inherentes a esta misma representación. Estas pasan por un momento de redefinición en la cual el dolor sobre la muerte de alguien querido se torna una especie de subjetivación, aislándose de lo social como una especie de dolor personal, ajeno a los intercambios objetivos societales (2001, p. 81).

Ana frente a la foto de su papá, generó una serie de acciones propias de quien se acerca a un cajón y besa la cara del muerto, aislándose por breves momentos, para generar ese lazo subjetivo con el muerto. Ella lo hizo simbólicamente acercando la foto de su papá a su cara y llorando sobre ella. Aunque la fotografía pertenece a un tiempo distante de la desaparición de su padre, casi dos años antes, es la representación de esa desaparición y la imagen proyectada en un tiempo circular la que le permite llorar. Frente a esa imagen, Ana siente la muerte de su papá y lo expresa con lágrimas y lamentos, transformando ese pequeño trozo de papel en una tumba efímera donde poder abrazarlo.

\section{Natalia}

Natalia es hija de Berta Cuesta Morales, desaparecida el 6 de agosto de 1975 y Daniel Colón, desaparecido el 12 de junio de 1975. Militantes del Ejército Revolucionario del Pueblo (ERP) Cada hijo experimenta sensaciones diversas cuando se enfrenta con imágenes de sus padres que imaginaban que pudieran existir. Natalia sintió la necesidad de escribir, mostrar, reflexionar sobre el lugar que ella ocupaba frente a esas fotografías. Para esto, marcó una temporalidad entre ellos y ella. Entre el pasado fijado en la imagen y su presente, entre esas miradas y la suya.

En el año 2010 recibí las fotos que documentaban la detención de mis padres en 1972 en el D2. Casi cuarenta años después. Tengo hoy más de diez años de los que ellos tenían cuando les sacaron esas fotos en las que los veo vulnerados. Y recuerdo que cuando era chica veía las fotos familiares y pensaba: ¿cómo no están acá para cuidarme? Hoy veo estas y pienso: ¿Cómo no estar ahí para cuidarlos?"16

16 APM-Córdoba. Video Documental: La foto de mis viejos. Video documental. Córdoba. Disponible en: < $\underline{\text { http:// }}$ apm.gov.ar/apm-historia-oral/>. Acceso en: 18 de abril de 2017. 
Figuras 5 e 6: Fotos Berta Cuesta Morales
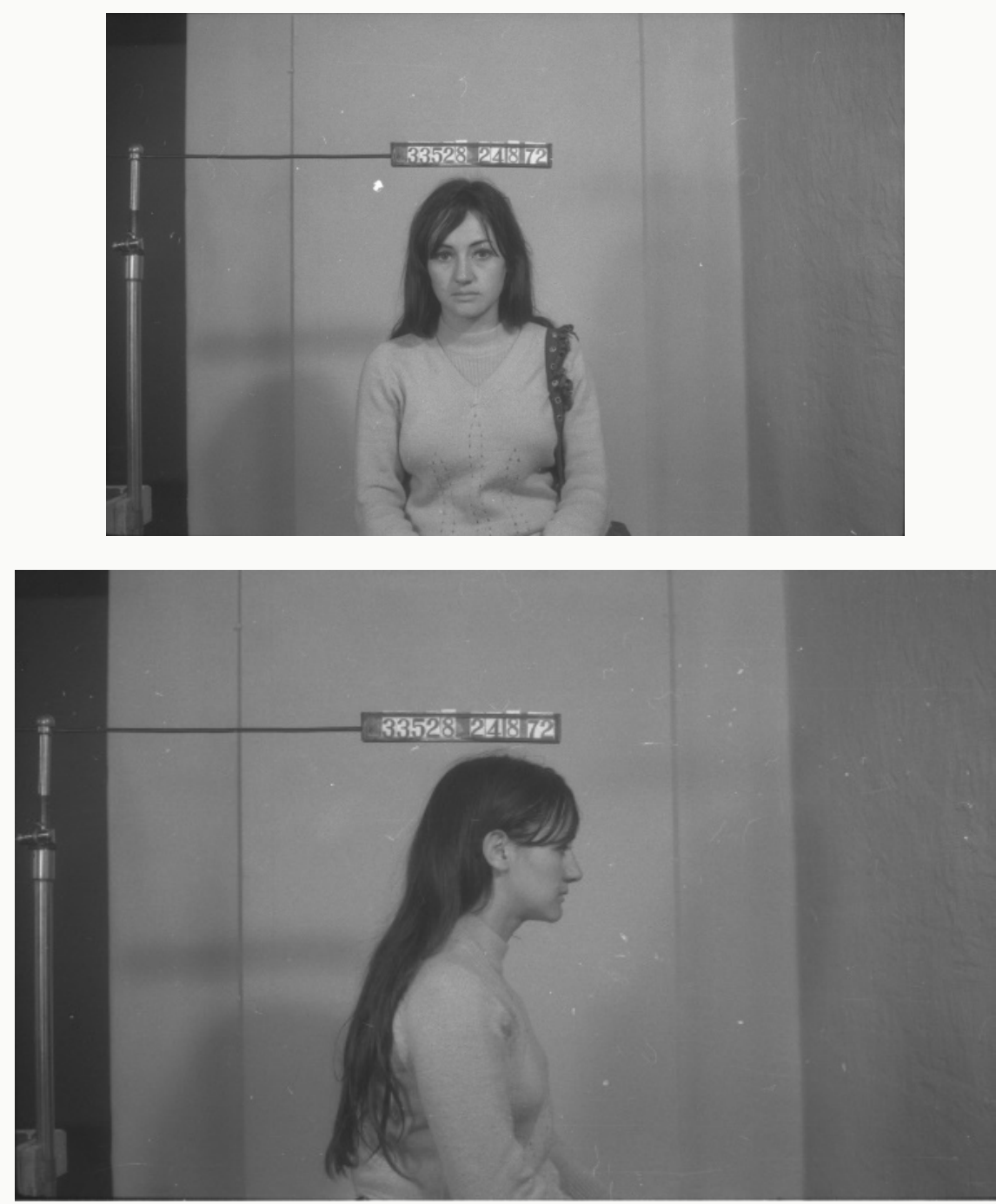

Fuente: Archivo Provincial de la Memoria de Córdoba. Registro de Extremistas.

Natalia, que es artista plástica, utilizó esas fotos en una exposición en el Archivo Provincial de la Memoria, que llevaba el nombre de su mamá: Berta. Allí expuso sobre una gran pared blanca una copia de los negativos de las imágenes. Uno debía acercarse para poder desentrañar de qué se trataba. La muestra era profundamente personal, cada objeto tenía que ver con su niñez y la búsqueda identitaria frente a la ausencia de sus padres desaparecidos. Un pequeño papel con la firma de su mamá. Un relato sobre sus abuelos. Y las fotos en negativo del Registro de Extremistas, que adquirían allí un nuevo sentido. Al elegir el negativo, generaba también la pregunta sobre lo que ellas revelan en las mismas paredes de lo que había sido el centro clandestino de detención del D2 y ahora sitio de memoria. Luego las retuvo en el espacio doméstico y les reservó un lugar en la última página del álbum de fotos familiar. Allí dentro del álbum eran "objetos fuera de lugar".

Los álbumes de familia son conjuntos coleccionados de retratos que aseguran el 
registro de los momentos significativos de la vida familiar de quien lo construye, atesora y custodia. Natalia, construyó su álbum fotográfico con restos, huellas, indicios que le permiten armar el rompecabezas de su propia vida dentro de la genealogía de la desaparición. Los tiempos se alteran, ella es más vieja hoy que sus padres frente a la muerte. La última foto de sus "viejos" es deseada y rechazada al mismo tiempo. Puede volver a nombrarlos frente a ese retrato policial, frente a la imagen de su madre desgarbada, que para ella, con su mirada desafía al policía que la registró. Quiere cuidarlos. Quiere estar allí. Esas imágenes, que retratan el precipicio de la muerte de sus padres, deben ser guardadas para asegurar su inmortalidad y su cuidado. Imágenes similares a las fotografías mortuorias, que ya casi nadie registra ni guarda y cumplen una función central de la expresión social, ya que buscan evocar un conjunto de situaciones que potencialmente puedan provocar nuevas posiciones sociales de los muertos, su familia y su derecho al luto.

\section{Construir y dejar huellas}

Gustavo, Carolina, Ana y Natalia buscan en cada uno de esos registros fotográficos las huellas de la vida y la muerte de sus padres. Cada uno pretende ver allí lo que no conoció de ellos, lo que imaginó o lo que le contaron y registró como los rasgos de su propia identidad. Los ojos, de esas mujeres y hombres desaparecidos nos/los siguen mirando más allá de que sus cuerpos no estén. La temporalidad entre la vida y la muerte se torna ambigua, la fotografía los retrotrae a ese momento imaginado de la muerte y permite el duelo. Poco importa si esa imagen tiene o no relación directa con ese instante preciso, pero funciona como catalizador de la muerte. Otras veces se transforma en un espacio de alivio que les permite construir alguna certeza al saber que sus padres pudieron sostener la mirada frente a sus victimarios. Gustavo lo siente junto a él. Carolina juega con la poesía y los colores. Ana llora y se abraza a la imagen de su padre. Natalia encuentra un lugar, el último, para ubicarlo en su álbum de fotos familiares.

Como bien recuerda Susan Sontag, cuándo dice que "las fotografías no pueden crear una posición moral, pero pueden colaborar para consolidarla" (1980, p. 27). La emoción, el compromiso social y político provocado por la imagen de un desaparecido, gana fuerza y se reactualiza por las diversas aproximaciones que cada espectador tiene frente a la noción de violencia extrema y muerte o de las que puede llegar a adquirir sugeridas por la imagen. Potencialmente funcionan como una transmisión, como aquella que mi abuela deseaba que yo incorporará al mostrarme a mis antepasados en sus fotos del panteón. Y es justamente por eso, porque todos compartimos experiencias y rituales frente a la muerte y lidiamos con ella desde los aprendizajes que supimos incorporar, que también podemos activar nuestros sentimientos y afectos a la hora de enfrentarnos con la fuerza que adquieren los rostros de los desaparecidos para interpelarnos. Nosotros espectadores, tal vez sólo vemos rostros de quienes ya no están, pero esos ojos, esos rasgos, inevitablemente evocan imágenes previas, así como interpelan sobre otras muertes y violencias que cotidianamente se suceden. Que 
provocan o deberían provocar la indignación y la compañía a sus seres queridos. Ya no para pensar sólo en nuestros muertos sino en los muertos de todos.

\section{Referencias Bibliográficas}

ALLUÉ, Marta. La ritualización de la pérdida. Anuario de Psicologia. Barcelona, v. 29, n. 4, p. 67-82, 1998. Disponible en: <http://www.raco.cat/index.php/AnuarioPsicologia/article/ view/61501/88348>. Acceso en: 15 de mayo de 2017.

BAUDRILLARD, Jean. Por qué la ilusión no se opone a la realidad. Cuadernos de Información y Comunicación, p. 193-202. Nov. 2004.

BARTHES, Roland. La cámara lúcida. Nota sobre la fotografía. Buenos Aires: Paidós, 2012. 188p.

BELTING, Hans. Antropología de la Imagen. Madrid: Katz Editores, 2009. 321p.

DA SILVA CATELA, Ludmila. No habrá flores en la tumba del pasado: La experiencia de reconstrucción del mundo de los familiares de desaparecidos. La Plata: Ediciones Al Margen, 2001. 301p.

DA SILVA CATELA, Ludmila. Lo invisible revelado. El uso de las fotografías como (re) presentación de la desaparición de personas en Argentina. In: FELD, Claudia y STITES MOR, Jessica. El pasado que miramos. Memoria e imagen ante la historia reciente. Buenos Aires: Paidós, p. 337-361, 2009.

DIDI-HUBERMAN, Georges. Imágenes pese a todo. Memoria visual del Holocausto. Barcelona: Paidós. 2004. p.264.

FAETA, Francesco. La mort en images. Terrain: anthropologie et sciences humaines. Paris, n. 20, p. 69-81, mar. 1993. Disponible en: <http://terrain.revues.org/3059>. Acceso en: 24 de febrero de 2017.

GALEANO, Eduardo. Entrevista sobre la muerte. Revista Ñ sábado, p. 1-2, 19 de abril de 2008.

GARCIA, Luis. Imágenes de ningún lugar. Sobre la representación del horror en Argentina. Nombres: Revista de Filosofia. Córdoba, ano 19, n. 23, p. 109-128, nov. 2009.

HALBWACHS, Maurice. A memória coletiva. São Paulo: Vértice, 1990. 189p.

HERNÁNDEZ CASTELLANO, Camilo. "La imagen en ruinas": muerte, memoria y representación en el desbarrancadero de Fernando Vallejo. Cuadernos de Literatura. Bogotá, v. 19, n. 37, p. 149168, 2015. Disponible en: <http://revistas.javeriana.edu.co/index.php/cualit/article/view/11879>. Acceso en: 20 de febrero de 2017.

HERTZ, Robert. La muerte y la mano derecha. Madrid: Alianza Editorial, 1990. 152p.

KOURY, Mauro (org.) Imagem e Memória: Ensaios em Antropologia Visual. Rio de Janeiro: 
Garamond, 2001. 189p.

LANGLAND, Victoria. Fotografía y memoria. In: JELIN, Elizabeth (Ed.). Escrituras, imágenes y escenarios ante la represión. Madrid, Buenos Aires: Siglo Veintiuno Editores, p. 87-91, 2005.

NORA, Pierre. Entre mémoire et histoire. La problématique des lieux. In: (org.). Les lieux de mémoire 1: La République. Paris: Gallimard, p. XVI-XLII, 1997.

PANIZO, Laura. Cuerpos desaparecidos. La ubicación ritual de la muerte desatendida. In: HIDALGO, Cecilia (Comp.). Etnografías de la muerte: Rituales, desapariciones, VIH/SIDA y resignificaciones de la vida. Buenos Aires: CLACSO, 2010, p. 17-40. Disponible en: <http:// bvsde.org.ni/clacso/publicaciones/hidalgo.pdf>. Acceso en: 12 de octubre de 2016.

PEIRANO, Marisa. A favor da etnografía. Rio de Janeiro: Relúme-Dumará, 1995. 180p. Disponible en: <http://www.marizapeirano.com.br/livros/a_favor_da_etnografia.pdf>. Acceso en: 29 de marzo de 2017.

ROSALDO, Renato. Cultura y Verdad. La reconstrucción del análisis social. Quito: Ediciones Abya-Yala, 2000. 251p. Disponible en: <http://dspace.unm.edu/bitstream/handle/1928/10760/ Cultura\%20y\%20verdad.pdf? sequence=1>. Acceso en: 29 de marzo de 2017

SCHMUCLER, Héctor. Ni siquiera un rostro donde la muerte hubiera podido estampar su sello. Confines. Buenos Aires, n. 3, s/p, set. 1996. Disponible en: <http://rayandolosconfines.com/ pc_schmucler.html>. Acceso en: 29 de marzo de 2017

SONTAG, Susan. Sobre la fotografía. Buenos Aires: Alfaguara, 1980. 288p.

TURNER, Víctor. La selva de los símbolos. Madrid: Siglo Veintiuno Editores, 1973. 468p.

VIGNOLO, Paolo (Ed.). Historias de vida en la ciudad de los muertos. Bogotá: Centro de Memoria, Paz y Reconciliación, 2015. 255p.

Recebido em: 07 de novembro de 2016

Aprovado em: 27 de abril de 2017 